\title{
THE PERMANENCE OF SOCIO-ECONOMICALLY MARGINAL STRUCTURES WITHIN URBAN SPACE: THE EXAMPLE OF BOGOTÁ*
}

\author{
Mirostawa CZerny \\ Faculty of Geography and Regional Studies, Warsaw University, Warsaw, Poland
}

Manuscript received September 9, 2011

Revised version October 17, 2011

\begin{abstract}
CZERNY M., The permanence of socio-economically marginal structures within urban space: The example of Bogotá. Quaestiones Geographicae 30(4), Bogucki Wydawnictwo Naukowe, Poznań 2011, pp. 47-54, 1 map, 4 photos, 1 table. DOI 10.2478/v10117-011-0037-6, ISBN 978-83-62662-88-3, ISSN 0137-477X.

AвSTRACT. The subject of this paper is an analysis of marginal spatial development processes taking place in Bogotá, one of the largest cities in the Southern Hemisphere. Bogotá, the capital of Colombia, situated on a high plateau (Sabana de Bogotá) at over 2,500 metres above sea-level, has currently approximately 8 million inhabitants. In Bogotá, as in any major South American city, we find the characteristic, highly pronounced diversification of urban space in terms of quality, urban landscape features, and living conditions. Marginal areas in Bogotá, characterised by a low quality of urban space, can be divided into two types, their origin and attributes linked to the general social processes that have taken place here in the 20th century. They are distinguished as follows: (a) marginal districts on the outskirts of the city, resulting from a period of dynamic and unplanned urbanisation, from the 1970s until now; and (b) marginal districts in the centre of the city. This article aims to show the mechanisms that contribute to the formation of and changes in these two types of urban space.
\end{abstract}

KEY WORDS: marginal urban spaces, social marginalisation, Bogotá

Mirostawa Czerny, Faculty of Geography and Regional Studies, Warsaw University, ul. Krakowskie Przedmieście 30, 00-927 Warsaw, Poland; e-mail: mczerny@uw.edu.pl

\section{Introduction}

The world in which we live is becoming predominantly urban space. The greater part of our globe's population is already living in cities. These are usually large urban centres where the growth dynamic is much greater than in smaller towns. While in 1950 only eight cities in the world had a population of over 5 million, today we have close to 50 such cities, including 20 major metropolitan areas with populations of over 10 million each. Of these mega-cities, the majority is located in developing countries. It is difficult to imagine the proper functioning and administration of such a city, as well as the accompanying problems caused by chaotic, unsupervised and unplanned urban expansion.

* This article was written under project "The old and the new in the space of Latin American Cites - the actors and contesters of change". All photos taken by the author. 
The subject of this paper is an analysis of marginal spatial development processes taking place in Bogotá, one of the largest cities in the Southern Hemisphere. Bogotá, the capital of Colombia, situated on a high plateau (Sabana de Bogotá) at over 2,500 metres above sea-level, has currently some 8 million inhabitants. In administrative terms, Bogotá is the capital district, and together with its surrounding 19 municipalities it constitutes a metropolitan region. In contrast to other large South American metropolitan areas, the majority $(3 / 4)$ of this metropolitan region's population resides in Bogotá itself. During the 2000 census, the area of the agglomeration was inhabited by 6.3 million people. In 2010 , the population was estimated at 8 million. While the population in the city centre has remained stable for two decades, it grows the fastest in the peripheral districts (localidades) of Chapinero, Santa Fé, Tunjuelito, and Barrios Unidos.

In Bogotá, as in any major South American city, we find the characteristic, highly pronounced diversification of urban space in terms of quality, urban landscape features, and living conditions. The existing deep socio-spatial divisions stem from many causes of political, social, economic and urban-planning nature. It is assumed that Bogotá's current varied spatial development is primarily due to political issues. While, of course, other factors also play an important role in this process, it is the history of the city (and the country), the political decisions meant to improve city management, as well as the city's specific spatial order, that have reinforced (and continue to influence) the divisions existing within the city. For this reason, this paper will focus on the ways and trends of spatial development in areas inhabited by the city's poorest social classes, as well as on their place in the spatial organisation of Bogotá (Czerny 2011).

\section{Socio-spatial segregation issues in Latin American cities}

Social differences, or even outright social segregation within urban space, are characteristic not only of Latin American cities. The concentration of residents with similar incomes and social status in certain areas of a city is typical of most ur- ban centres in the modern world. In the Spanish colonies which gained independence in the early 19th century, the process of segregation in urban space began at the time of economic changes - industrialisation (in the second half of the 19th century), and marginalisation (coupled with a total lack of social reform) of the indigenous (Indian) and mestizo masses, who were denied the many important benefits of democratic society. The Spanish influence, and later economic policies of the independent states themselves, headed by Creole elites (descendants of the Spanish), led to the reinforcement of social divisions. The Creole elites, educated in Europe, took over power in the independent republics, but preserved and often reinforced the old, colonial social divisions (e.g. the institution of serfdom was truly abolished in Ecuador only in the 1970s; Czerny 2011a).

Samuel Jaramillo (1998) argues that one can make out two stages in the formation of sociospatial segregation patterns in Latin American cities (and perhaps we are now observing the emergence of a third). In the colonial period (the first stage of development), a city's built environment was dense, its built-up area small, and its development linked to the function and position it had in the colonial administrative hierarchy. The city centre had the most significant role as the seat of political, military and religious authority. The buildings surrounding the city's main square (often called Plaza de Armas, 'Military Square', because of the drills conducted there) included colonial administration headquarters, military barracks, and a cathedral or the city's most important church. The city residents were first Spanish, then Creole, with their Indian and mestizo servants. Although most of the latter lived near the city margins, some lived in the homes of their masters, which meant that the physical distance between the two social classes was not great (Jaramillo 1998).

With economic growth and the development of trade with Europe and North America, Latin American cities saw the arrival of new migrants merchants, industrialists, workers, etc. - not just from Spain, but from all of Europe. The Creole elites began to leave the city centre, migrating beyond the existing zone of urban development. The function of the city centre began to diversify, as new actors - banks, trading companies and 
numerous other institutions - appeared. A middle class began to form with the arrival of immigrants from Europe, particularly in the late 19 th and early 20th centuries. The dual social division characteristic of the colonial era gradually disappeared, especially in the cities, giving way to a class society in which the middle class grew in economic and political significance. The middle class began to take over the homes left by the Creole ruling class, dividing the traditional colonial houses (which usually had two or three inner patios) into several premises, also locating manufacturing plants or other business there. Indians and mestizos, with no financial means to set up their own businesses, hired themselves out to work for these new arrivals, usually for extremely low wages. Few of them were then able to enter the middle class; those that did were usually artisans or merchants. They built their homes in the least attractive areas located on the outskirts of the city, on former haciendas and estancias previously owned by powerful landlords, which, as the city grew, were divided up and sold as plots to be built up. Poor city residents often occupied this land without the right to do so, and it was only with time that they formally acquired this right. The term 'pirate districts' (barrios piratas), still in use today, originated to describe the illegal takeover of land for the building of housing structures. Jaramillo (1998) calls this process "strong macro-segregation".

\section{Bogotá - a place of refuge and anonymity}

Until the mid-20th century, the urbanisation process in Colombia was characterised by relatively balanced growth of its large cities. In this respect, Colombia stood out from among its neighbours in the Andean region. Beside the capital, other dynamically developing cities were Cali, Medellín and Barranquilla. Their population (around 800 thousand) was close to that of Bogotá (slightly over 1 million). The situation started to change diametrically in the 1980s, although it had already been unstable in rural Colombia earlier. Violence caused by internal conflicts and the beginnings of the drug mafia (the production and export of marijuana in the 1960s and '70s) caused people from areas affected by the civil war (violencia) to flee to Bogotá. From the 1980s on, the conflicts began to spread across the entire country. Cocaine mafias and paramilitary groups, well established in remote, hard-to-reach parts of the country, caused the number of refugees to soar, especially since the 1990s when those groups started to throw out whole families from their villages. The refugee population is estimated at several million. In 2010 alone, the number of refugees fleeing from rural regions to the big cities was estimated at 280 thousand (www.eltiempo.com/archivo/documento/CMS-8867220). Most sought an asylum in Bogotá, Medellín, Cali and Barranquilla. One can encounter the opinion that Bogotá is a great refugee camp. Such phenomena must have an effect on the spatial processes taking place in the city. The result is rapid population growth. The new arrivals often have no means to live on and - in the short term - their situation only becomes worse. Rural refugees are less educated than the city dwellers; they constitute an unskilled labour force, and their only chance of survival is through employment in the informal sector (Sáenz Acosta 2007).

\section{Marginalised (low-quality) areas in Bogotá}

In Bogotá, marginalised areas characterised by a low quality of urban space can be divided into two types, their origin and attributes linked to the general social processes that took place here in the 20th century. Those are: (a) marginal districts on the outskirts of the city, resulting from a period of dynamic and unplanned urbanisation from the 1970s until today, and (b) marginal districts in the centre of the city.

(a) Immigrants from rural areas, who have been coming to Bogotá since the 1970s and whose influx is due to the unstable situation in the Colombian countryside, settle mainly on the outskirts of the city. They establish illegal settlements, which at first resemble a cluster of plastic tents. Here they live in extremely primitive conditions, with no drinking water, electricity, plumbing, or social infrastructure. Lack of paved roads makes these provisional settlements initially impossible to reach by modes of transport. Such a settlement 


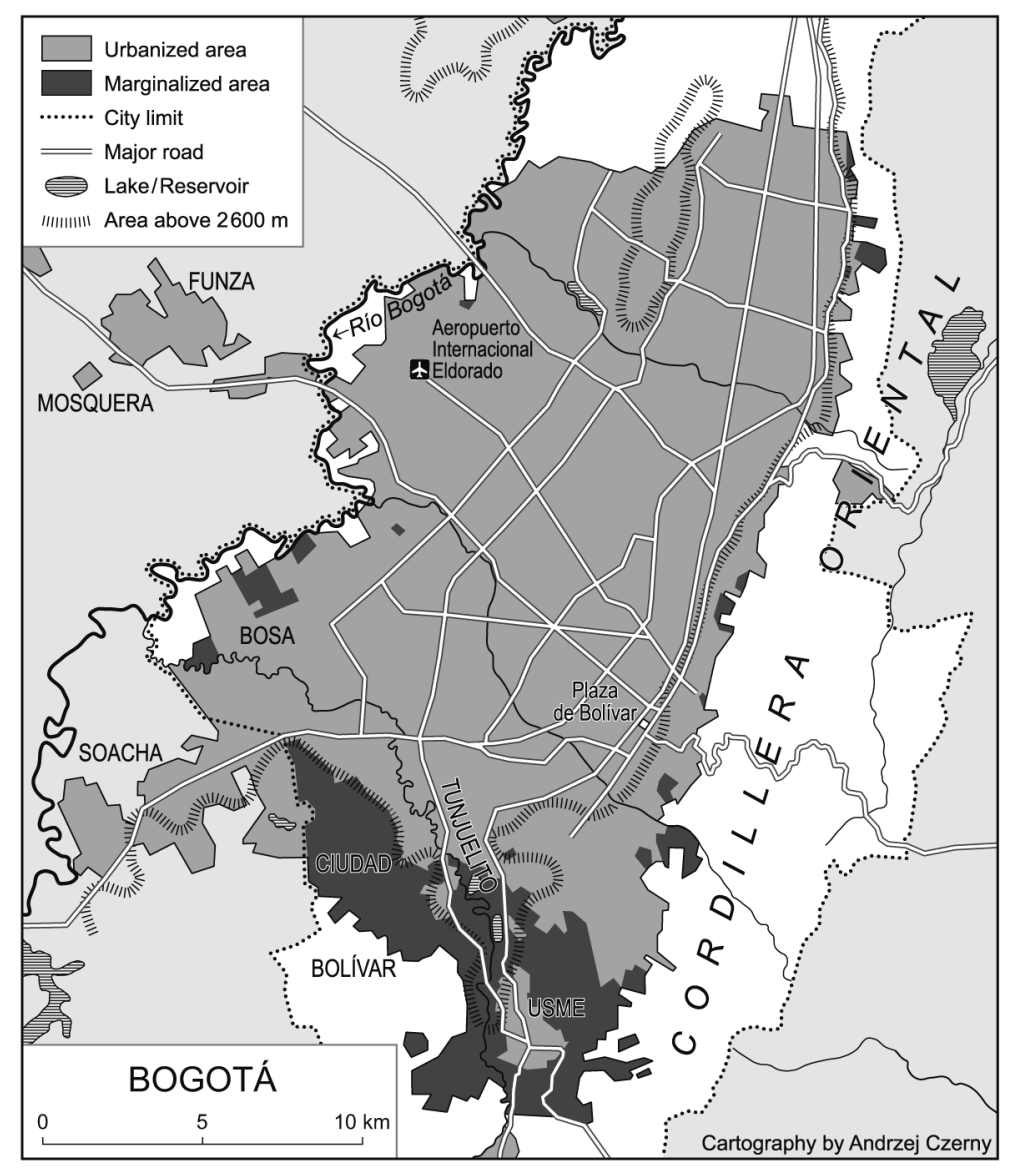

Map 1. Marginal districts in Bogotá.

is only temporary. Gradually, it begins to change, a process typical of most marginal settlements in Latin America. The immigrants get organised, forcing the city authorities to recognise the settlement as legal, making it possible to bring in physical infrastructure - first electric power as the easiest, then, in order of complexity, a watersupply system and sewage facilities. Often the residents themselves take part in the building of the necessary infrastructure. As they gradually become accustomed to living in the city and join the ranks of workers of the informal sector, their initially temporary shelter begins to take on the form of a home, with one room serving as the living quarters and the other housing a business, such as a small shop, workshop, or stockroom. As the family income grows, so does the house, usually by acquiring a second storey.

Illegal dwellings on the city outskirts can be of two subtypes. The first is barrios piratas, or 'pirate districts'. While constructed on small, legally bought plots of land, the building structures themselves, as well as the fixtures and installations inside, follow no plan and lack the neces- sary permits. That is why this way of building is considered illegal. The other subtype is invasiones, when houses are built on state-owned land; in the case of Bogotá, on mountaintops or slopes where construction is forbidden to prevent erosion and landslides (Sáenz Acosta 2007).

(b) The history of the transformation and pauperisation of city centres in Latin America is long, going back at least to the late 19th and early 20th centuries. As mentioned earlier, at that time the Creole elites were leaving city centres, which was connected with the arrival of new migrants, who in turn settled there, dividing the old colonial houses also into parts where business could be carried out. In the 1970s, the descendants of those migrants, who are part of the middle class today, also started to leave city centres for other urban districts with higher standards of living (e.g. with parks and recreational facilities). The centre has been left to the city's poor, some of the old colonial houses have been converted into warehouses, workshops, inexpensive hotels and guest houses. Many buildings in the original colonial city centres have been demolished, becoming temporary 


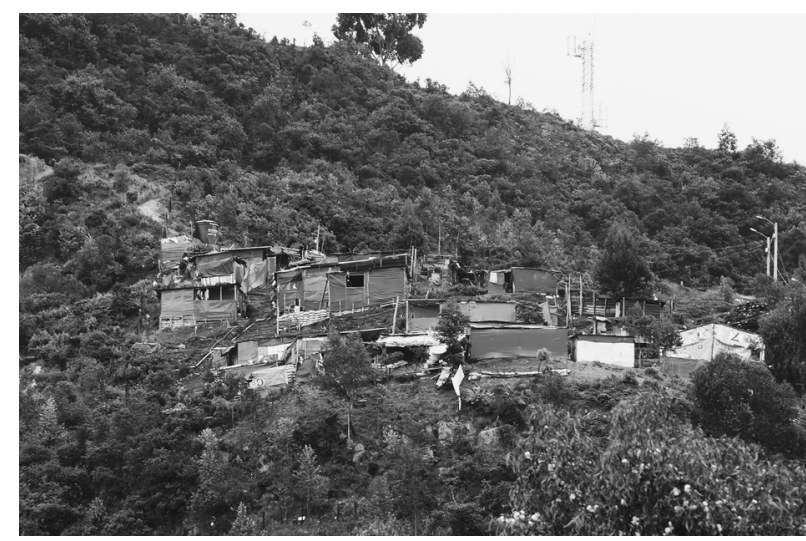

Photo 1. Invasiones - illegally occupied areas on the slopes and tops of mountains surrounding Bogotá.

parking lots while the land awaits a better investor. The number of such buildings demolished within the fabric of the colonial city centre of Bogotá is staggering. The municipal authorities want to salvage those colonial architectural landmarks, but are unable to attract investors interested in renovating them. So far, the buildings have been turned into hotels or guest houses attracting tourists from abroad, particularly young. In the recent years, several galleries and shops selling traditional folk art have also appeared.

There is no precise definition of marginal or dilapidated areas in formal city planning nomenclature. The loose translation of the expression used to describe them in Spanish, areas urbanas deprimidas, is "depressing-looking urban areas." Also lacking is a clear division between official definitions (employed in urban planning documents) and those in everyday language, often used by the press. The inability of the official language to reflect reality is indicative of an evolution and permanent changes that have been taking place in urban marginal regions over the last four decades.

The term for settlements that began appearing spontaneously on the city periphery in the early years of the accelerated urbanisation process (the 1970s), and which looked like clusters of huts or temporary tents, constituting a highly primitive part of the urban fabric, was tugurios. This term, along with its definition given above, started appearing in official documents. Even though today it is the most common term used to describe marginal settlements, with dwellings not meeting all the standards required of proper housing, it is increasingly more difficult to find in offi-

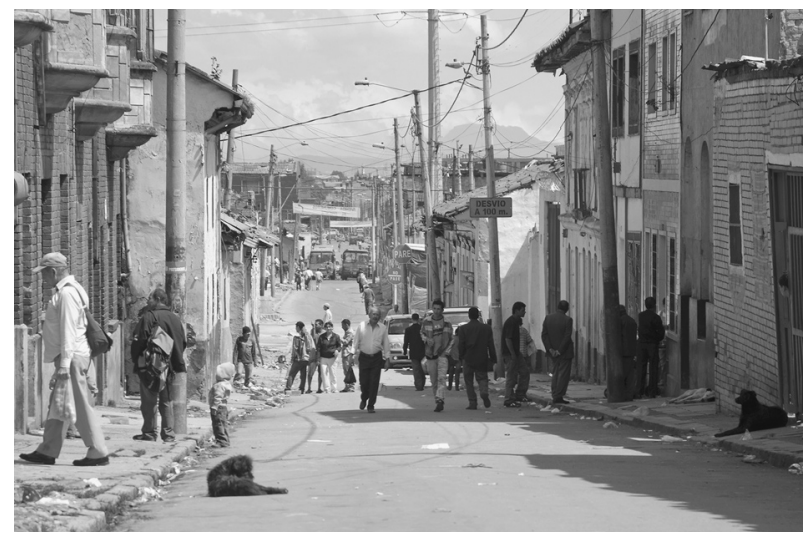

Photo 2. Degradation of the central area of the city.

cial documents. Instead, in spatial development plans one is much more likely to encounter such terms with reference to the initial stage of the unplanned and spontaneous urbanisation process as barrios informales (informal districts, DAPD 2000: 74), asentamientos subnormales (subnormal settlements, DAPD 2000: 111) and asentamientos de origen clandestino (settlements of clandestine origin, DAPD 2000: 159). Besides, the Unidad Coordinadora de Política Habitacional (the Housing Policy Coordination Unit, 2002) has adopted the term desarrollos ilegales (illegal development). It could be said that these terms are synonymous and correspond to the following general definition: the settlements in question are urban, with the land occupied and the dwellings developed without official building permits and without the involvement of urban planning institutions (Unidad Coordinadora de Política Habitacional 2002). Due to the lack of road infrastructure, public services, schools and health-care facilities, as well as the makeshift nature and substandard quality of the dwellings, the living conditions of the entire community are extremely poor (UribeMallarino 2008).

In the recent years, city authorities have adopted a policy of integrating marginal districts, which involves social aid programs for the residents. For this reason, the use of pejorative language to refer to the residents or to the illegal origin of most of the settlements is avoided. In accordance with the spatial development plan for Bogotá, infrastructure improvement programmes, such as Programa de Mejoramiento Integral de Barrios (DAPD 2000: 347), are being introduced in marginal areas, replacing earlier programmes like Er- 


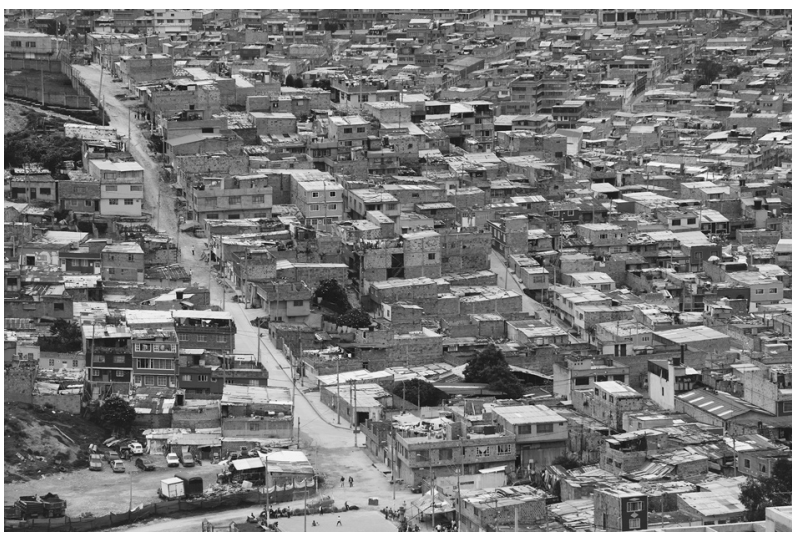

Photo 3. A settlement turning from illegal to legal, with brick houses and a network of urban infrastructure.

radicación de Tugurios (1960-1980) and Desmarginalización de Barrios (1998-2000) (Uribe-Mallarino 2008).

In the mid-20th century, the destroyed central city quarters were known as inquilinatos. According to a definition provided by the Departamento Administrativo de Planeación Distrital (DAPD, the Administrative Department for District Planning), those are "large houses from the early 20th century in which families live permanently, occupying individual rooms and sharing a bathroom, a kitchen, and a patio, used to dry the laundry" (DAPD 1997: 66-68). In the 1960s, inquilinatos located in the city centre were the main places receiving immigrants who arrived in the city and sought this type of shelter to spend the first years in, and who later moved to the 'unplanned' settlements being built on the city's periphery. Inquilinatos still exist, but their number has decreased, and so has their significance as the only type of shelter the immigrants were initially able to find. This function has been taken over by rooms for rent in the many houses built on the city's periphery by those who have moved there, now serving them as an additional source of income.

Besides inquilinatos, the city centre includes sections characterised by a high degree of devastation, inhabited by groups on the lowest rungs of Bogotá's social ladder. Although their share in the city's overall area is not great, the levels of poverty, drug abuse and crime in some of those quarters is extremely high. There is no specialised, generally known term referring to them. A DAPD document from 1977 mentions a Zona de Desviación Social and a Zona de Tolerancia u Olla, terms used to describe an area of the city inhab-

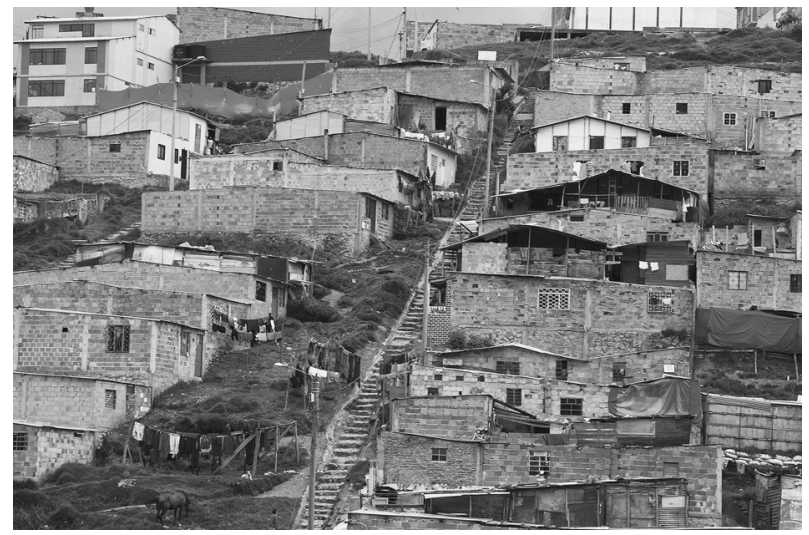

Photo 4. A settlement with legalised housing, gradually transforming into a regular city quarter.

ited predominantly by social groups associated with criminal activity, prostitution, and drug trafficking and consumption (DAPD 1997: 68). To come across this type of expressions in official documents is highly unusual; as a rule, they are used colloquially.

What is notable above all about the marginal, peripheral regions of Bogotá is that they are seen as unsafe. That is why most of the city's residents call them asentamientos piratas - not fulfilling building standards and attracting newly arrived, poor people from the countryside. The informal origin of these settlements combines the taking of land for illegal home building with the migrants' disadvantaged place in society - illegal work, difficulties integrating with the rest of society, etc. Crime, off-the-books employment, a low level of education, and ill health are elements typical of the residents of those districts, and largely attributed to poverty. Therefore, the terms used to refer to the marginal districts - illegally built and lacking various amenities - relate to this situation. They include: barrios marginales, barrios piratas, invasiones, cinturones de miseria, ollas, huecos, barrios pobres, and other expressions referring not only to the living conditions in the particular locality, but also to its residents. Generally, those from the highest echelons of society do not know these districts from personal experience, but from the mass media or second-hand accounts, already distorted at the source. One can therefore say that the dominating mental image and representation of the city's poorest regions does not reflect the actual situation; rather, it perpetuates suspicion and mistrust, making them unknown and fear-inspiring territories. 


\section{Conclusions}

The original centre of Bogotá, which had served as a political, financial, cultural and social centre of the city and the country for over four centuries, has experienced a transformation which was inevitable given the unstable political situation that Colombia has found itself in during the last three decades. In the case of Bogotá, the intense urban expansion into the peripheral areas that has taken place over the past 30 years, planned only in part and hence insufficiently, has led to the breakdown of the monocentric structure, so characteristic of colonial and post-colonial cities until the mid-20th century. Uncontrolled urban growth coupled with an underdeveloped public transport system, and the appearance of various service centres in suburban neighbourhoods targeted at local residents - these are the main causes of the fragmentation and segregation of urban space. Because of decentralisation and deconcentration, the city centre has lost some of its significant and prestigious functions, which in turn has contributed to a slowdown on the real-estate market and loss of property value. Efforts of the city authorities to reintegrate the centre with the rest of the city and to restore it to its former glory have led to large-scale road construction and other transport development projects encompassing the entire historical area of the city. Today the old city centre is surrounded by a ring of government offices and business establishments; this is also where most of Bogotá's institutions of higher learning are located. Thanks to this process, the "expanded" centre (centro expandido), as it is called, is much larger than the original, which was confirmed by the Plan de Ordenamiento Territorial (POT) for the years 2000-2010.

The consequences of the existence of neglected areas (deprimidas), marginal in the process of urban growth and development, are generally negative. Nonetheless, from the point of view of their residents, illegal urban development was undoubtedly a rational solution (Vernez 1974) to the critical problems (lack of housing and jobs) arising from the accelerated urbanisation process that started in the second half of the 20th century. Illegal forms of urbanisation (and barrios piratas in particular) became the only way of survival for numerous immigrant families unable to find legitimate housing and employment in the city. Public aid programmes were extremely limited at the time, with both the cost and type of housing not well suited for families accustomed to country life. In 1970, the time critical for the urbanisation process, only $10.7 \%$ of families in need were able to secure housing under government programmes, while $46.4 \%$ opted for the illegal market which allowed them to tailor their living quarters to their needs and financial abilities (Valenzuela \& Vernez 1974).

The traditional model of spatial segregation in a capitalist city, often used to analyse spatial transformation processes in Latin American cities (Bähr \& Mertins 1981, Borsdorf 1976, Gormsen 1981), is slowly losing significance in the face of abrupt changes currently taking place in the structure of those cities. A city in the Andean region experiences a fragmentation of its districts, their clearly visible consolidation within specified spaces, and low inter-district (inter-class) mobility of the residents.

Besides, the latest studies call attention to the emergence of a new stage in the formation of the socio-spatial structure of the city as a result of the earlier model of "macro-segregation": in the recent years, residents with higher incomes have been coming back to the central districts to live. Ameliorating the "repeated peripheralisation" phenomenon, new middle-class housing estates

Table 1. Poor people in 2001 in selected localidades (districts) in thous.

\begin{tabular}{|c|c|c|c|c|c|}
\hline Localidad & $\begin{array}{c}\text { Poorest popula- } \\
\text { tion }\end{array}$ & Poor population & $\begin{array}{c}\text { Lowest level of } \\
\text { poverty (miseria) }\end{array}$ & $\begin{array}{c}\text { Level of poverty } \\
\text { (pobreza) }\end{array}$ & $\begin{array}{c}\text { Total population } \\
\text { in localidad }\end{array}$ \\
\hline Santa Fé & 3.4 & 72.7 & 3.7 & 18.6 & 107.1 \\
\hline Usme & 66.4 & 182.5 & 14.4 & 62 & 251.3 \\
\hline Bosa & 3.8 & 393.1 & 12.5 & 74.7 & 427.5 \\
\hline Ciudad Bolívar & 279.3 & 288.1 & 44.1 & 159.5 & 600.4 \\
\hline Bogotá D.C. & 445.9 & $2,378.9$ & 167.6 & 893.5 & $6,496.5$ \\
\hline
\end{tabular}

Source: Alcaldia Mayor de Bogotá (2001), after Rueda García \& Rueda Sinisterra (2005). 
are built inside districts inhabited by lowerincome families. The return of the higher social classes to the city centre has some consequences for its spatial organisation, however: an increase in the number of gated communities and the competition for land in, or near, the city centre, which leads to the demolition (both legal and illegal) of the colonial houses making up the historical fabric of the city.

Secondly, the type of people making use of the traditional city centre is also changing. Used mostly by common people, this area has also started to attract bohemians and small investors making the effort to renovate the old houses and convert them into hotels. Hence, it appears that after a period of decline, the city centre stands a chance of becoming dynamic again, that is, if the colonial houses are not illegally demolished and replaced with car parks first.

\section{References}

Bähr J. \& Mertins G., 1981. Idealschema des sozialräumlichen Differenzierung lateinamerikanischer Großstädte. Geographische Zeitschrift, 69(1): 1-33.

Borsdorf A., 1976. Valdivia und Osorno. Strukturelle Disparitäten in chilenischen Mittelstädten. Tübinger Geographische Studien, 69. Tübingen.

Czerny M., 2011. Bogota's social-spatial structure and its permanence in the city's spatial planning landscape. In: Czerny M. \& Tapia Quevedo J. (eds), Metropolitan areas in transition. WUW, Warszawa: 87-104.
Czerny M., 2011a. Miasta globalnego Południa - chaos czy porzacdek przestrzenny (Cities of the global South - spatial chaos or order?). In: Kaczmarek S. (ed.), Miasto. Ksiegga jubileuszowa w 70. rocznice urodzin Profesora Stanistawa Liszewskiego. Wydawnictwo Uniwersytetu Łódzkiego, Łódź: 181-198.

Departamento Administrativo de Planeación Distrital, 1997, 2000.

Gormsen E., 1981. Die Städte im spanischen Amerika. Ein zeit-räumliches Entwicklungsmodell der letzten hundert Jahre. Erdkunde, 35(4): 290-303.

Jaramillo S., 1998. El destino del centro de Bogotá. Revista Desarrollo y Sociedad, 10. CIDER, Universidad de Los Andes, Bogotá.

Proyecto de acuerdo no. 201 de 2008. Por medio del cual se establece el estrato uno (1) para los predios donde funcionen hogares comunitarios y sustitutos legalmente autorizados en lo relacionado con el cobro de servicios públicos domiciliarios de energía y gas.

Rueda García N. \& Rueda Sinisterra D., 2005. Desarrollo urbano y pobreza en Bogotá D.C. Universidad de Los Andes, Bogotá.

Sáenz Acosta H., 2007. Consideraciones acerca de una nueva pauta de segregación socioespacial en Bogotá, a través de un análisis de caso: la irrupción de unidades de clase media en aéreas de ocupación popular. Bogotá.

Uribe-Mallarino C., 2008. Estratificación social en Bogotá: de la política pública a la dinámica de la segregación social. Universitas Humanistica, Enero-Junio: 139-171

Valenzuela J. \& Vernez G., 1974. Construcción popular y estructura del mercado de vivienda: el caso de Bogotá. Revista Interamericana de Planificación, 31: 89-140.

Vernez G., 1974. A housing services policy for low-income urban families in underdeveloped countries. New York City - Rand Institute, New York.

http:/ / www.eltiempo.com/archivo/documento/CMS8867220. 